\title{
DAMPAK KOMPETENSI PROFESIONAL GURU DALAM MENINGKATKAN MUTU PENDIDIKAN MADRASAH IBTIDAIYAH DI KOTA SALATIGA
}

\author{
Nur Hasanah \\ Institut Agama Islam Negeri Salatiga \\ nurhasanab201157@yahoo.com
}

\begin{abstract}
This study aimed to determine the professional competence of teachers in Islamic Elementary School, factors that influence professional competence, and the impact of professional competence of teachers in improving the quality of education in Islamic Elementary School in Salatiga. This qualitative research covers only three of them taken as purposive sampling. Data collection was conducted through in depth interview, observation, and documentation. The results shows that the competence of Islamic Elementary School Teachers in Salatiga hasnot done the mastery of learning based on technology, observation and development. This can cause low employee motivation, lack of learning facilities, the work ethic are still low, academic supervision, and socioeconomic conditions. Low-impact in the competence of professional teachers is caused by non optimal learning, ineffective and inefficient learning, less comfortable and enjoyable learning, less innovative, dynamic and productive learning results.
\end{abstract}

Keywords: Teacher Profesionalism Competence; Quality of Education, Islamic Elementary School

\begin{abstract}
Abstrak
Penelitian ini bertujuan mengetahui kompetensi profesional guru Madarasah Ibtidaiyah, faktor-faktor yang mempengarubi kompetensi profesional guru Madrasah Ibtidaiyah dan dampak kompetensi profesional guru dalam meningkatkan mutu pendidikan Madrasah Ibtidaiyah di Kota Salatiga. Jenis penelitian ini adalah kualitatif dengan mengambil sampel tiga Madrasab Ibtidaiyah di Kota Salatiga. Pengumpulan data dilakukan dengan wawancara mendalam, observasi, dan dokumentasi. Hasil penelitian menunjukkan bahwa kompetensi profesional guru Madrasah Ibtidaiyah Kota Salatiga belum melakukan penguasaan media pembelajaran berbasis teknolog, penelitian dan pengembangan. Rendabnya motivasi kerja, kurangnya fasilitas pembelajaran, etos kerja yang masih rendah, supervisi akademik, dan kondisi sosial ekonomi. Dampak rendah kompetensi profesional guru adalah pembelajaran kurang optimal, pembelajaran kurang efektif dan efisien, pembelajaran kurang nyaman dan menyenangkan, hasil pembelajaran kurang inovatif, dinamis dan produktif.
\end{abstract}

Kata Kunci: Kompetensi Profesional Guru, Mutu Pendidikan, Madrasah Ibtidaiyah

Permalink/DOI: http://dx.doi.org/10.18326/infs13.v9i2.445-466 


\section{Pendahuluan}

Dalam menghadapi persaingan global Madrasah Ibtidaiyah sebagai lembaga pendidikan Islam harus dituntut untuk meningkatkan kualitas pendidikannya. Dari sejarah lahirnya sampai sekarang telah mengalami berbagai perkembangan yang pesat seirama dengan perkembangan bangsa Indonesia. Dimulai dari sistem pendidikan di pengajian dirumah-rumah, terus ke musholla, masjid dan kebangunan sekolah seperti bentuk madrasah yang kita kenal sekarang ini (Husni Rahim, 2004:23).

Tujuan utama dari pendidikan Madrasah Ibtidaiyah adalah menyiapkan anak didik yang dapat memadukan iptek dan imtak. Hal ini sebagaimana harapan masyarakat pada madrasah. Berdasarkan harapan tersebut maka visi madrasah ke depan yang sesuai dengan khittah awalnya adalah populis, Islami, dan berkualitas. Visi ini merupakan gambaran yang diinginkan terhadap madrasah berdasarkan potensi,semangat keagamaan dan histories lahirnya madrasah di Indonesia.

Realita secara umum kondisi madrasah masih di bawah standar sekolah terutama madrasah swasta. Hal ini dapat dilihat Sumber Daya Manusia (SDM) yang masih kurang baik dari segi kuantitas maupun kualitas,kurang menguasai agama, kurang sesuai dengan keahliannya. SDM yang dimaksud adalah guru. Guru merupakan komponen pertama dan utama dalam menentukan keberhasilan pembelajaran siswa.

Peserta didik MI masih dalam kategori usia dini (6 - 15 Tahun). Pada usia dini merupakan usia yang paling tepat untuk meletakkan pondasi pendidikan Islam yang berupa pendidikan tauhid,agar keimanannya kuat. Oleh karena itu maka dalam upaya membantu siswa untuk mencapai perkembangan potensinya sesuai dengan nilai-nilai ajaran Islam diperlukan guru yang profesional sebagaimana yang menjadi keahliannya.

Upaya Kementerian Agama untuk meningkatkan kualitas dan kesesuaian madrasah dengan kebutuhan masyarakat sudah dilakukan diantaranya dengan dibukanya program kualifikasi guru Madrasah Ibtidaiyah, agar guru memiliki kompetensi sebagaimana 
guru profesional. Upaya tersebut bagus sebagai solusi dalam meningkatkan kompetensi guru, namun dalam kenyataannya masih ada faktor atau hambatan yang mempengaruhinya sehingga perlu dicari solusinya.

Hal ini sebagaimana perkembangan Madrasah Ibtidaiyah di Salatiga secara fisik madrasah sudah mengalami perubahan dan kemajuan melaui bantuan DAK dari pemerintah namun secara substansial masih belum sepenuhnya dilakukan pembenahan seperti halnya peningkatan kompetensi profesional guru secara maksimal, sehingga belum signifikan dengan prestasi yang dicapainya. Keberhasilan mutu pendidikan di madrasah masih rendah, prestasinya di bawah sekolah umum (SD). Profesionalisme guru merupakan salah satu faktor yang menentukan keberhasilan mutu pendidikan di Madrasah Ibtidaiyah.

Berdasarkan latar belakang masalah tersebut, maka peneliti tertarik untuk mengetahui 1) bagaimana kompetensi profesional guru Madarasah Ibtidaiyah dalam meningkatkan mutu pendidikan Madrasah Ibtidaiyah di Kota Salatiga; 2) apa faktor-faktor yang mempengaruhi kompetensi profesional guru Madrasah Ibtidaiyah di Kota Salatiga?; 3) bagaimana dampak kompetensi profesional guru dalam meningkatkan mutu pendidikan Madrasah Ibtidaiyah di Kota Salatiga?.

\section{Kompetensi Profesional}

Kompetensi profesional guru adalah seperangkat pengetahuan, ketramiplan, pengalaman yag dimiliki dan dikuasai oleh guru dalam menjalankan tugasnya (jabatan atau pekerjaannya) sebagai guru. Kompetensi profesional merupakan suatu keharusan dimiliki oleh guru dalam upaya meningkatkan kualitas pendidikan.

Menurut Islam kompetensi profesional guru mencakup tiga hal yaitu personal-religius, sosial-relegius, dan sosial-relegius (Muhaimin, 1993:173). Kompetensi tersebut dapat dijabarkan dalam kompetensi sebagai berikut:

1. Mengetahui dan menguasai materi yang diajarkan

2. Mempunyai kemampuan menganalisis materi yang diajarkan melalui interaksi edukasi 
3. Mengamalkan terlebih dahulu informasi yang telah didapat sebelum disajikan pada anak didik

4. Mengevaluasi proses dalam dan hasil pendidikan yang sedang dan sudah dilaksanakan

5. Memberi hadiah (tabsyir) dan hukuman (tandzir) sesuai usaha anak didik dalam rangka motivasi dalam proses pembelajaran

6. Memberikan uswatun hasanah dalam meningkatkan kualitas dan profesionalnya.

Penelitian yang dilakukan oleh Sri Hartini (2006) tentang faktor-faktor strategis yang mempengaruhi kompetensi guru dalam pembelajaran (Studi kasus pada guru MTsN Salatiga) yang kesimpulannya adalah kompetensi guru dipengaruhi oleh beberapa faktor antara lain etos kerja, tingkat pendidikan, dan latar belakang sosial ekonomi. Penelitian yang dilakukan oleh Ika Widi Astuti (2009) tentang kompetensi profesional guru PAI Madrasah Aliyah Al-Hikmah Gunung Kidul yang kesimpulannya adalah guru MA Gunung Kidul sudah memiliki kompetensi profesional yaitu dalam menyusun materi, menyampaikan materi dan pengembangan materi. Penelitian yang dilakukan oleh Hj.Kasiana (2009) tentang pengaruh kompetensi guru dalam meningkatkan mutu lulusan SDN Kayen IV Kec. Ilir Barat Palembang yang kesimpulannya adalah kompetensi guru memiliki pengaruh yang signifikan dengan mutu lulusan SDN Kayen IV kec. Ilir Barat Palembang.

\section{Asas-asas Kompetensi Profesional Guru}

Menurut Samana (1994:70 - 75) dari 11 kompetensi profesional guru tersebut dalam pelaksanaannya diperlukan prinsip-prinsip/ asas-asas pembelajaran yang tepat yang meliputi :

1. Asas siswa aktif

Pada dasarnya anak adalah makhluk yang aktif. Hal ini dapat dipertanggungjawabkan dari misi vilosovis, psikologis, biologis, dan sosiologis yang bertalian dengan kehidupan anak. Pembelajaran merupakan kegiatan kemanusiaan yang fundamental, maka wajarlah guru dan siswa dituntut aktif dalam meaksanakan perannya. Karena belajar pada dasarnya 
bagaimana membelajarkan siswa.

2. Asas motivasi dalam dalam belajar

Motivasi merupakan dorongan yang menjadikan seseorang melakukan kegiatan belajar. Motivasi ini dapat bersifat intrinsik dan ekstrinsik.Guru dituntut untuk cakap membangun motivasi belajar siswa.

3. Asas pusat minat

Dalam upaya membangun minat siswa guru hendaknya berusaha keras untuk menjelaskan makna, arah, kegunaan, keindahan, keunikan, dan nilai positif dari bahan yang wajib dipelajari oleh siswa. Guru dituntut menguasai bahan ajar secara mendalam, berstruktur, sehingga siswa belajar sesuatu yang bermakna dalam interaksinya dengan guru.

4. Asas apersepsi, korelasi dan integrasi

Penerapan asas apersepsi dalam pembelajaran adalah penyandaran serta penggunaan pengetahuan yang telah dimiliki oleh siswa sebagai titik tolak pembahasan bahan ajar yang baru. Sedangkan Penerapan asas korelasi dalam pembelajaran adalah menghubungkan antar data, konsep, prinsip, dan generalisasi yang menjadi pembahasan agar keseluruhan hasil belajar jelas, mendalam, dan berstruktur. Dan penerapan asas integrasi dalam pembelajaran adalah mengutuhkan perolehan belajar siswa yang ditandai dengan :

a. Setiap konsep, prinsip, dan generalisasi yang baru dikuasai oleh siswa hendaknya terekam dalam sistem berpikir yang semakin kompak dan fungsional (kiat problim solving).

b. Penguasaan siswa diaspek teoritis mengejawantah dalam kecakapan praktisnya (teori dan praktik dikuasai siswa secara terpadu).

5. Asas individualisasi

Dalam asas ini pembelajaran hendaknya disesuaikan dengan kondisi, potensi, sifat, minat, taraf perkembangan, dan kebutuhan siswa. Guru hendaknya dapat mengatur kelas 
secara fleksibel. Penerapa asas ini yang berhasil ditandai dengan optimalisasi perolehan belajar siswa selaras dengan potensinya, perkembangan multi talent (seluruh aspek) serta bakatnya berkembang secara wajar dan berimbang), integrasi diri, dan para siswa mengalami keluasan hidup.

6. Asas peraga

Asas peragaan merupakan konkritisasi pesan pembelajarn agar mudah dikuasai oleh siswa. Oleh karena itu guru dituntut untuk menguasai media dan teknologi pembelajaran.

7. Asas kooperasi

Asas kooperasi dalam pembelajaran adalah pengaturan kerja kelompok dan pembinaan kompetensi yang sehat. Variasi pengelompokan, arahan dinamika kelompok, intimitet antar anggota, kejelasan tujuan serta hasil kerja kelompok merupakan topik yang perlu didalami oleh guru dalam membina belajar siswa. Persaingan yang sehat antar siswa dalam kelompoknya, yang ditandai dengan sikap realistis, usaha yang gigih , tetap terbuka untuk saling membantu, dan keterbukaan akan kritik sehubungan dengan proses serta hasil kerja tetap perlu diusahakan guru dalam pembelajaran. Kooperasi dan kompetensi jangan dipandang sebagai dua kutub yang saling tarik menarik, tetapi perlu diusahakan oleh guru agar kompetensi justru jadi penggerak dinamika kelompok dan dasar pelayanan bimbingan belajar perorangan. Dan perlu ditegaskan bahwa prinsip-prinsip kerja kelompok yang baik adalah kejelasan tujuan, kadar partisipasi serta tanggungjawab anggota, prosedur kerja yang jelas,adanya iklim demokratis serta menyenangkan ,dan adanya penilaian serta pengembangan lebih lanjut.

8. Asas pengajaran multi sumber

Dalam asas ini guru dituntut mampu menjabarkan serta mengorganisasikan bahan ajar secara sistematis dengan mendaya gunakan aneka sumber belajar yang semakin banyak dalam masyarakat. Dan mengingat taraf kematangan berpikir siswa ,guru hendaknya mampu menjabarkan serta mengorganisasikan bahan ajar dengan kajian yang bersifat komparatif, kontekstual, 
selain disiplin keilmuan, penuh alternatif , dan sistematisintegratif.

9. Asas kesinambungan belajar

Penerapan asan berkesinambungan ini tampak dalam:

a. Pendampingan proses belajar siswa secara efektif-efisien. (mencapai hasil belajar yang terstandar).

b. Tersedianya kondisi (fasilitas) dan situasi belajar yang kondusif,

c. Adanya tata urutan bahan ajar atau pengalaman belajar yang terkait secara sistematis dan logis serta sesuai dengan kebutuhan siswa.

d. Siswa perlu menguasai perangkat pengetahuan untuk kepentingan belajar, misalnya: kecakapan berbahasa, kecakapan inkuiri, kecakapan sintesis-analisis secara logis.

10. Asas penilaian

Penilaian dalam pembelajaran dapat digunakan untuk mengetahui mutu kerja guru dan mutu belajar siswa. Data penilaian dapatdigunakan sebagai umpan balik bagi guru dan siswa untuk berbenah diri serta mencari perkembangan lebih lanjut.

\section{Tugas, Peran, dan Tanggung Jawab Guru}

Guru merupakan jabatan atau profesi yang memerlukan keahlian khusus sebagai guru. Pekerjaan ini tidak dapat dilakukan oleh orang yang tidak memiliki keahlian untuk melakukan pekerjaan sebagai guru. Oleh karena itu guru profesional memiliki tugas utama sebagai agen pembelajaran. Menurut Mulyasa (2008: 53) tugas guru sebagai agen pembelajaran antara lain adalah:

1. Guru sebagai fasilitator

Dalam hal ini guru hendaknya dapat meberikan kemudahan belajar kepada peserta didik, agar anak didik belajar dalam suasana yang menyenangkan, gembira, penuh semangat, dan berani mengemukakan pendapat secara terbuka. Dengan 
demikian dapat menjadi modal dasar bagi peserta didik untuk tumbuh dan berkembang menjadi manusia yang siap beradaptas, menghadapi berbagai kemungkinan, dan memasuki era globalisasi yang penuh berbagai tantangan.

Sehubungan dengan tugas guru sebagai fasilitator tersebut maka menurut Rogers dalam Mulyasa (2008: 55) guru harus memiliki sikap sebagai berikut :

a. Tidak berlebihan mempertahankan pendapat dan keyakinannya, atau kurang terbuka.

b. Dapat lebih mendengarkan peserta didik, terutama tentang aspirasi dan perasaannnya.

c. Mau dan mampu menerima ide peserta didik yang inovatif, dan kreatif, bahkan yang sulit sekalipun.

d. Lebih meningkatkan perhatiannya terhadap hubungan dengan peserta didik seperti halnya terhadap bahan pembelajaran.

e. Dapat menerima feedback, baik yang sifatnya positif maupun negatif dan menerimanya sebagai pandangan yang konstruktif terhadap diri dan perilakunya.

f. Toleransi terhadap kesalahan yang diperbuat oleh siswa selama proses pembelajaran.

g. Menghargai prestasi peserta didik meskipun mereka sudah tahu prestasi yang dicapai.

Singkatnya guru itu harus siap menjadi fasilitator yang demokratis profesional, karena dalam kondisi perkembangan informasi, teknologi, dan globalisasi yang begitu cepat, tidak menutup kemungkinan bahwa dalam hal tertentu peserta didik lebih tahu dulu dari guru. Mungkin mereka memiliki berbagai media, seperti internet. Kondisi ini menuntut guru untuk senantiasa belajar meningkatkan kemampuan, mampu dan siap menjadi pembelajar sepanjang hayat. 
2. Guru sebagai motivator

Dalam hal ini tugas guru harus mampu membangkitkan semangat belajar peserta didik sehingga mencapai tujuan pembelajaran. Oleh karena itu guru harus memperhatikan prinsip-prinsip sebagai berikut:

a. Peserta didik akan bekerja keras kalau memiliki minat dan perhatian terhadap pekerjaannya.

b. Memberikan tugas yang jelas dan dapat dimengeri.

c. Memberikan penghargaan terhadap hasil kerja dan prestasi peserta didik.

d. Memberikan penilaian dengan adil dan transparan.

3. Guru sebagai pemacu belajar

Sebagai pemacu belajar, guru harus mampu mengembangkan potensi peserta didik sesuai dengan aspirasi dan cita-cita di masa yang akan datang. Dalam hal ini maka guru harus kreatif, profesional, dan menyenagkan dengan memposisikan dirinya sebagai:

a. Orang tua yang penuh kasih sayang pada peserta didik.

b. Teman, tempat mengadu, dan mengutarakan perasaan bagi peserta didilk.

c. Fasilitator yang selalu siap memberikan kemudahan, dan melayani peserta didik sesuai minat, kemampuan, dan bakatnya.

d. Memberikan sumbangan pemikiran kepada orang tua untuk dapat mengetahui permasalahan yang dihadapi anak dan memberikan saran pemecahan.

e. Memupuk rasa percaya diri, berani dan bertanggung jawab.

f. Membiasakan peserta didik untuk saling berhubungan dengan orang lain secara wajar.

g. Mengembangkan proses sosialisasi yang wajar antar peserta didik, orang lain, dan lingkungan. 

h. Mengembangkan kreativitas.
i. Menjadi pembantu ketika diperlukan.

4. Guru sebagai pemberi inspirasi belajar

Sebagai pemberi inspirasi belajar, guru harus mampu memerankan diri dan mampu memberikan inspirasi peserta didik, sehingga kegiatan pembelajaran dapat membangkitkan berbagai pemikiran, gagasan, dan ide-ide baru. Iklim belajar yang kondusif merupakan faktor pendorong yang dapat memberikan daya tarik dalam proses pembelajaran, dan sebaliknya iklim belajar yang kurang menyenangkan akan menimbulkan kejenuhan dan rasa bosan.

Adapun peran guru dalam pelaksanaan pembelajaran menurut Mulyasa (2008: 19) adalah sebagai berikut:

1. Sebagai pendidik dan pengajar

Setiap guru harus memiliki kestabian emosi, ingin memajukan peserta didik, bersikap realistis, jujur, dan terbuka, serta peka terhadap perkembangan, terutama inovasi pendidikan. Untuk mencapai semua itu guru harus memiliki pengetahuan yang luas, menguasai berbagai jenis bahan pembelajaran, menguasai teori dan praktek pendidikan, serta menguasai kurikulum dan metodologi pembelajaran.

2. Sebagai anggota masyarakat

Setiap guru harus pandai bergaul dengan masyarakat. Untuk itu harus menguasai psikologi sosial, memiliki pengetahuan tentang hubungan antar manusia, memiliki ketrampilan bekerjasama dalam kelompok, dan menyelesaikan tugas bersama dalam kelompok.

3. Sebagai pemimpin

Setiap guru adalah pemimpin yang harus memiliki kepribadian , menguasai ilmu kepemimpinan, prinsip hubungan antar manusia, teknik komunikasi, serta menguasai berbagai aspek kegiatan organisasi sekolah. 
4. Sebagai administrator

Setiap guru akan dihadapkan pada berbagai tugas administrasi yang harus dikerjakan di sekolah.sehingga harus memiliki kepribadian yang jujur, teliti, rajin, serta memahami strategi dan manajemen pendidikan.

5. Sebagai pengelola pembelajaran

Setiap guru harus mampu dan menguasai berbagai metode pembelajaran dan memahami situasi belajar-mengajar di dalam maupun di luar kelas.

Sedangkan tanggungjawab guru adalah sebagai berikut:

a. Tanggungjawab moral, bahwa guru harus mampu menghayati perilaku dan etika yang sesuai dengan moral pancasila dan mengamalkannya dalam pergaulan hidup sehari-hari.

b. Tanggungjawab dalam bidang pendidikan di sekolah, bahwa setiap guru harus menguasai pembelajaran yang efektif , mampu mengembangkan kurikulum, silabus, dan rencana pelaksanaan pembelajaran, melaksanakan pembelajaran yang efektif, menjadi model bagi peserta didik, memberikan nasehat, dan melaksanakan evaluasi hasil belajar.

c. Tanggungjawab dalam bidang kemasyarakatan, bahwa setiap guru turut serta mensukseskan pembangunan yang harus kompeten dalam membimbing, mengabdi, dan melayani masyarakat (Mulyasa, 2002: 18)

Kompetensi profesional harus dimiliki oleh seorang guru, karena kemampuan profesional menunjukkan apa dan bagaimana melakukan pekerjaan dan penguasaan rasional mengapa hal itu diakukan berdasarkan konsep dan teori tertentu.

Rendahnya pengakuan masyarakt terhadap kompetensi profesi guru menurut Cece Wijaya (1991: 22) disebabkan beberapa faktor antara lain:

1. Pandangan sebagian masyarakat siapapun dapat jadi guru, asal berpengetahuan. 
2. Banyak guru tidak menghargai profesinya apalagi mengembangkan kompetensinya.

Faktor-faktor tersebut disbabkan oleh kebanyakan kendala yang dihadapi guru, yaitu realitas pragmatis kehidupan . Persoalan kemasyarakatan sebagai bagian dari komunitas sosial, kehidupan keluarga, ekonomi dan tanggungjawab, menuntut jawaban yang serius. Usaha yang harus dilakukan adalah dimulai dari guru, dengan mengakui secara sadar makna peofesi itu, menghayati dan mencintai tugas profesinya, serta berusaha mengembangkan kompetensi profesional yang disandangnya dengan rasa tanggungjawab sebagai usaha pengakuan dan pengukuhan profesi guru.

Setidaknya ada tiga ciri pokok yang menjadi pekerjaan yang bersifat profesional. Secara berturut-turut adalah pekerjaan itu disiapkan melalui proses pendidikan dan pelatihan secara formal, mendapat pengakuan dari masyarakat dan ditandai dengan organisasi profesi. Sedang tugas guru sebagai profesi meliputi mendidik, mengajar dan melatih. Mendidik berarti meneruskan dan mengembangkan ilai-nilai hidup. Mengajar berarti meneruskan dan mengembangkan ilmu pengetahuan dan teknologi. Sedang melatih berarti mengembangkan ketrampilan pada siswa.

Untuk dapat meningkatkan kompetensi profesional guru setidaknya ada tiga syarat dasar yang harus dipenuhi, yaitu :

1. Kemampuan di bidang kognitif, artinya kemampuan intelektual, penguasaan mata pelajaran, pengetahuan tentang cara mengajar, bimbingan penyuluhan, pengetahuan cara belajar dan tingkah laku indivdu, administrasi kelas dan sebagainya.

2. Kemampuan dibidang sikap (afektif), artinya kesiapan dan kesediaan guru terhadap berbagai hal yang berkenaan dengan tugas-tugas profesinya.

3. Kemampuan perilaku (psikomotorik), yaitu kemampuan guru dalam berbagai ketrampilan dan perilaku (performance).

Sudah barang tentu ketiga bidang kemampuan tersebut tidak berdiri sendiri tetapi saling berhubungan dan saling mempengaruhi. Usaha yang dapat dilakukan untuk meningkatkan kompetensi profesionalisme guru adalah wawasan keilmuan dan metodologi 
guru dengan tidak hanya mengedepankan model top down dari pemerintah selaku pemegang otoritas pendidikan yang dilakukan, para prktisi pendidikan seperti supervisor, pengawas, dan pimpinan sekolah. Hal ini akan berkembang cepat jika usaha itu diikuti dengan kesadaran guru sebagai sikap yang kondusif serta tetap mengembangkan tradisi yang ada selama ini seperti MGMP (Musyawarah Guru Mata Pelajaran), KKG (Kelompok Kerja Guru) di sekolah lanjutan.Namun kelemahan yang terjadi ialah cenderung kurang serius dalam kegiatan ini, sekedar menyamakan hal-hal yang sifatnya pragmatis, bagaimana menyiapkan bahan tes, membuat rencana pelajaran dan sebagainya. Begitu juga supervisi akademik hendaknya dilakukan untuk membantu guru mengembangkan kompetensi profesionalnya. Sehingga melalui supervisi akademik diharapkan kualitas pembelajaran meningkat.

Adanya kualitas pembelajaran yang meningkat berarti mutu pendidikan juga meningkat. Mutu pendidikan yang dimaksud adalah mencakup input, proses, dan output (Depdiknas, 2001: 25). Input pendidikan adalah segala sesuatu yang harus tersedia karena dibutuhkan untuk berlangsungnya proses. Sesuatu yang dimaksud adalah berupa sumberdaya dan perangkat lunak serta harapan-harapan sebagai pemandu bagi berlangsungnya proses. Input sumberdaya meliputi: kepala madrasah/sekolah, guru, siswa, sumberdaya selebihnya adalah sarana prasarana, dana, dan perlengkapan lainnya.Sedangkan input perangkat lunak adalah struktur organisasi sekolah, peraturan-peraturan perundangundangan, rencana, dan sebagainya. Dan input harapan-harapan berupa visi, misi, tujuan, dan sasaran-sasaran yang ingin dicapai sekolah. Kesiapan input sangat diperlukan agar proses berlangsung dengan baik. Oleh karena itu tinggi rendahnya mutu input dapat diukur dari tingkat kesiapan input.

Proses Pendidikan merupakan berubahnya sesuatu menjadi sesuatu yang lain. Sesuatu yang berpengaruh terhadap berlangsungnya proses disebut input, dan sesuatu dari hasil proses disebut output. Dalam kelembagaan berskala mikro proses yang dimaksud adalah proses pengambilan keputusan, proses pengelolaan kelembagaan, proses pengelolaan program, proses belajar mengajar , dan proses monitoring dan evaluasi. Proses belajar mengajar dalam 
hal ini memiliki tingkat kepentnigan tertinggi dibandingkan dengan proses-proses lainnya.

Proses dikatakan bermutu apabila pengkoordinasian dan penyerasian input sekolah (guru, siswa, fasilitas, dan kurikulum dan sebagainya) dilakukan secara harmonis sehingga mampu menciptakan situasi pembelajaran yang menyenangkan, mampu mendorong motivasi dan minat siswa, dan benar-benar mampu memberdayakan peserta didik.

Output pendidikan adalah merupakan kinerja sekolah. Kinerja sekolah prestasi sekolah yang dihasilkan dari proses sekolah. Kinerja sekolah dapat diukur dari kualitasnya, efektivitasnya, produktivitasnya, efisiensinya, inovasinya, kualitas kehidupan kerjanya, dan moral kerjanya.Dan khusus yang berkaitan dengan mutu sekolah dapat ditunjukkan dengan prestasi siswa dalam bidang akademik, dan non akademik. Mutu sekolah dipengaruhi oleh banyaknya kegiatan yang saling berhubungan seperti perencanaan, pelaksanaan, dan pengawasan.

Dengan demikian dapat dipahami bahwa guru memiliki peran yang penting dalam meningkatkan mutu pendidikan, aspek guru terletak pada proses pendidikan, sehingga bagaimana guru dapat memberdayakan peserta didik dalam pembelajaran? Kompetensi profesional guru yang baik itulah yang dibutuhkan.

\section{Metode Penelitian}

\section{Pendekatan Penelitian}

Penelitian ini merupakan penelitian kualitatif dengan pendekatan deskriptif. Karena data yang dikumpulkan berbentuk kata atau gambaran dari naskah wawancara, cacatan lapangan, dokumen pribadi (Moleong, 2002: 11). Bentuk penelitian ini akan mampu menangkap berbagai informasi kualitatif dengan deskriptif yang penuh nuansa, yang lebih berharga dari pada sekedar pernyataan jumlah atau frekwensi dalam bentuk angka (Sutopo, 1990: 12). 


\section{Subyek Penelitian}

Permasalahan yang akan diungkap dalam penelitian ini adalah kompetensi guru maka yang menjadi subyek (key informan) dalam penelitian ini adalah kepala madrasah, guru, siswa, dan komite Madrasah Ibtidaiyah di Kota Salatiga. Mereka dipilih sebagai key informan karena mereka yang lebih paham tentang kondisi madrasah. Sedangkan informan sekunder dalam penelitian ini adalah tokoh masyarakat yang lebih memahami persepsi madrasah.

Subyek yang dimaksud dalam penelitian ini adalah guruguru dan siswa MI di Kota Salatiga yang berada pada 12 MI yang tersebar di empat kecamatan, yang meliputi :

1. Kecamatan Sidomukti : MI Mangunsari, MIN Kecandran, MI Dukuh

2. Kecamatan Sidorejo : MI Global Blotongan, MI Pulutan, MI Kauman Lor

3. Kecamatan Tingkir, MI Canden, MI Kalibening, MI Tingkir Lor

4. Kecamatan Argomulyo : MI Kumpulrejo I, MI Kumpulrejo II, MI Noborejo

Dari sejumlah 12 MI tersebut peneliti hanya mengambil tiga MI sebagai sampel penelitian, yaitu : MI Kalibening, MI Pulutan, dan MI Global Blotongan. Adapun alasan peneliti mengambil sampel tiga MI tersebut antara lain karena ketiga MI tersebut memiliki prestasi akademik maupun non akademik yang baik dari sejumlah MI Kota Salatiga dan MI tersebut statusnya swasta (Hasil wawancara dengan ketua KKG MI Kota Salatiga Tanggal 2 Agustus 2012).

\section{Teknik Pengumpulan Data}

Teknik pengumpulan data yang digunakan dalam penelitian ini adalah wawancara, observasi, dan studi dokumentasi. Wawancara dilakukan untuk memperoleh data tentang kompetensi profesional guru MI Kota Salatiga. Adapaun subyek yang diwawancarai adalah guru, siswa, dan komite sekolah MI Kalibening, MI Pulutan dan MI Blotongan.

Sedangkan teknik analisis data dilakukan melalui analisis diskriptif model interaktif yang dikembangkan oleh Miles dan 
Huberman (1992: 16). Analisis data model ini terdiri atas komponenkomponen yang saling berinteraksi yaitu reduksi data, penyajian data, dan penarikan kesimpulan atau verifikasi.

\section{Analisis}

Kompetensi Profesional Guru

Berdasarkan hasil wawancara dengan guru-guru MI kalibening, MI Pulutan, dan MI Blotongan pada tanggal 13 September 2012 dan 17 diperoleh data bahwa latar belakang pendidikan guru di MI Kalibening mayoritas S1 dan sudah PNS, sedangkan guru-guru MI Pulutan latar belakang pendidikannya mayoritas S1 tapi belum PNS, dan untuk guru guru MI Global sudah S1 tapi belum PNS. Latar belakang pendidikan guru-guru tersebut mayoritas berasal dari alumni STAIN dan menjadi guru kelas. Hal ini dapat dilihat dalam tabel sebagai berikut :

Tabel 1 .

Keadaan Guru MI Kota Salatiga Tahun 2012

\begin{tabular}{|c|c|c|c|c|c|}
\hline NO & NAMA MI & $\begin{array}{c}\text { JLH } \\
\text { GURU }\end{array}$ & IJAZAH & $\begin{array}{c}\text { STATUS } \\
\text { GURU }\end{array}$ & $\begin{array}{c}\text { GURU } \\
\text { KLS/GURU } \\
\text { MAPEL }\end{array}$ \\
\hline 1 & $\begin{array}{c}\text { MI } \\
\text { Kalibening }\end{array}$ & $\begin{array}{c}13 \\
\text { orang }\end{array}$ & $\mathrm{S} 1$ & $\begin{array}{c}\text { PNS (8orang) } \\
\text { dan non PNS } \\
\text { ( } 5 \text { orang }\end{array}$ & $\begin{array}{l}10 \text { orang } \\
\text { guru kelas }\end{array}$ \\
\hline 2 & MI Pulutan & $\begin{array}{c}16 \\
\text { orang }\end{array}$ & S1 & $\begin{array}{c}\text { PNS } \\
\text { (1 orang) }\end{array}$ & $\begin{array}{c}\text { Guru kelas } \\
\text { semua }\end{array}$ \\
\hline 3 & $\begin{array}{l}\text { MI Global } \\
\text { Blotongan }\end{array}$ & $\begin{array}{c}12 \\
\text { orang }\end{array}$ & $\mathrm{S} 1$ & $\begin{array}{c}\text { PNS } \\
\text { (3 orang) } \\
\text { dan non PNS } \\
\text { (9 orang) }\end{array}$ & $\begin{array}{c}2 \text { Orang } \\
\text { guru mapel } \\
\text { dan } 10 \\
\text { orang guru } \\
\text { Kelas }\end{array}$ \\
\hline
\end{tabular}


Dari hasil wawancara tersebut dapat diketahui bahwa kompetensi profesional guru Madrasah Ibtidaiyah di Kota Salatiga dapat dikatakan baik.Meskipun masih ada beberapa kompetensi yang belum dimiliki oleh guru seperti disiplin ilmu yang sesuai materi yang diampu dalam mengajar. Penguasaan media berbasis teknologi informrmasi, dan melakukan research and development. Hal ini sebagaimana yang dikemukakan oleh (Asmani, 2009: 163) bahwa guru yang profesional mutlak memiliki kompetensi (kemampuan) ilmu, penguasaan pedagogis (metodologi pembelajaran).

Kompetensi ilmu dicapai dengan banyak belajar membaca, menulis, meniliti, mengikuti seminar, simposium, dan sebagainya. Kompetensi ilmu ini berindikasi pada penguasaan materi secara mendalam dan dinamis, melakukan penelitian (research and development), menjadi produsen ilmu pengetahuan, menguasai tertib administrasi, dan mengembangkan kreativitas. Kompetensi metodologi dicapai dengan penguasaan teori-teori belajar, metode pembelajaran, model-model pembelajaran dan penguasan IPTEK yang berkaitan dengan pembelajaran.

Dilihat dari SDMnya dalam hal ini guru-guru MI Kota Salatiga banyak yang guru kelas dibandingkan guru bidang studi sehingga kurang menguasai materi pembelajaran yang disampaikan. Namun dalam metode pembelajaran guru-guru MI pada umumny mengajar sudah menggunakan metode yang tepat dan menggunakan media pembelajaran yang sederhana, meskipun media pembelajarn berbasisi teknologi yang masih minim jumlahnya, seperti leptop, LCD, dan kelas multi media. Bahkan fasilitas seperti ruang laboratorium Bahasa, laboratorium Komputer, lab. IPA, lab. Kimia, Lab Fisika juga belum ada. Padahal media pembelajaran berbasis teknologi sangat banyak manfaatnya bagi guru maupun siswa dalam pembelajaran, karena teknologi merupakan sumber belajar dan sebagai alat komunikasi. Dengan demikian guru dan siswa tidak gagap teknologi atau melek teknologi. Secara umum guru-guru sudah melakukan penilaian dalam pembelajaran untuk mengetahui sejauhmana keberhasilan mengajar dengan tes tertulis.

Berdasarkan hasil wawancara dengan guru MI Pulutan pada tanggal 17 September 2012 diperoleh data bahwa dari 17 
guru yang sudah PNS baru satu guru dan belum lolos sertifikasi. Dari hasil wawancara ini dapat diketahui bahwa guru MI Pulutan tersebut hampir semuanya guru honorer atau wiyata bakti, sehingga penghasilannya belum sesuai dengan standar upah minimal. Sedangkan APBNnya hanya dari BOS untuk oprasional kegiatan madrasah. Dengan demikian data tersebut membuktikan bahwa pada umumnya guru-guru MI belum pernah melakukan penelitian dalam mengembangkan keilmuannya yang disebabkan oleh kurang adanya alokasi dana dari lembaga yang dibutuhkan. Padahal dari hasil penelitian yang dilakukan sangat banyak manfaat bagi guru disamping menambah ilmu pengetahuan juga dapat meningkatkan kreativitas pembelajaran dan menyesuaikan adanya perubahan dan perkembangan zaman (inovatif).

\section{Faktor-Faktor Yang Mempengarubi Kompetensi Profesional Guru}

Faktor-faktor yang mempengaruhi kompetensi profesional guru Madrasah Ibtidaiyah di Kota Salatiga adalah sebagai berikut:

1. Motivasi guru

Kompetensi guru Madrasah Ibtidaiyah dalam melaksanakan tugas berorientasi pada APBS (Anggaran Pendapatan Belanja Sekolah) atau dengan kata lain alokasi dana madrasah dari BOS. Hal itu sekaligus sebagai motivasi kerja guru seperti melakukan penelitian kalau ada dananya.

2. Fasilitas kerja

Pada umumnya kinerja guru diabatasi oleh fasilitas lembaga seperti kurangnya media pembelajaran yang meliputi: LCD, kelas multi media ruang laboratorium IPA, ruang laboratorium bahasa, ruang laboratorium komputer dan sebagainya ,sehingga pembelajaran kurang efektif dan efisien.

3. Etos kerja

Sebagian besar kemauan dan semangat guru Madrasah Ibtidaiyah masih kurang sehingga dalam melaksanakan tugas belum optimal. Sikap kemandirian dalam melaksanakan tugas belum sepenuhnya dimiliki oleh guru padahal tugas mengajar adalah profesi yang harus bisa dilakukan dengan sepenuh 
hati (ikhlas karena Allah). Hal ini dapat diketahui dari hasil wawancara dengan salah satu guru yang berinisial Ag pada tanggal 15 September 2012.

4. Supervisi akademik

Berdasarkan hasil penelitian kepala madrasah jarang melakukan supervisi akademik. Sehingga guru kurang mengetahui sejauhmana keberhasilan dalam mengajar. Guru mengajar mengikuti paradigma lama yang sudah ada. Padahal dengan supervisi akademik akan menjadi feed back dalam penilaian mengajar guru, sehingga guru dapat melakukan perbaikan dalam pembelajaran.

5. Latar belakang sosial ekonomi

Sebagian kecil guru MI berstatus swasta dan belum dapat sertifikasi. Jadi penghasilan guru diperoleh dari honorarium madrasah yang hasilnya belum sesuai dengan UMR (upah minimum regional). Sehingga dalam melaksanakan tugas kurang maksimal.Sedangkan lokasi MI pada umumnya berada dipinggiran kota sehinga kurang mendukung penghasilan ekonomi guru.

Dampak Kompetensi Profesional Guru dalam Meningkatkan Mutu Pendidikan

Dengan adanya beberapa kompetensi profesional yang belum dilakukan oleh guru Madrasah Ibtidaiyah di Kota Salatiga tersebut maka dampaknya terhadap mutu pendidikan Madarasah Ibtidaiyah di Kota Salatiga sebagai berikut:

1. Masih kurangnya pengusaan ilmu pengetahuan yang dimiliki guru akan membawa dampak pada hasil pembelajaran yang kurang baik. karena tugas mengajar adalah bagaimana guru dapat membelajarkan siswa, yang dalam hal ini mengajar adalah proses. Maka guru dalam mengajar hendaknya sesuai dengan bidang keilmuan. Menurut Asmani (2009: 165) guru yang mengajar sesuai dengan bidangnya akan termotivasi untuk mengembangkan kemampuannya semaksimal mungkin, ada kepuasan batin dalam jiwanya untuk mencapai tingkat tertinggi 
dalam kemampuannya dan anak didik akan tercerahkan dengan pemikiran dan gagasan yang dinamis, kompetitif, dan produktif.

2. Kurangnya fasilitas yang digunakan guru dalam pembelajaran maka hasil pendidikan kurang efektif dan efisien. Terutama fasilitas pembelajaran yang berbasis teknologi. Dengan terbatasnya media pembelajaran berbasis teknologi dalam pembelajran maka siswa kurang termotivasi dalam pembelajaran, siswa kurang nyaman menikmati proses pembelajaran, dan kurang menumbuhkan semangat berkompetisi untuk meraih hasil yang baik dalam pembelajaran.

3. Aspek penilaian yang sering dilakukan guru dalam pembelajaran adalah aspek kognitif sehingga hasil pembelajaran yang dicapai siswa kurang komprehensif (menyeluruh).Kompetensi sikap dan ketrampilan yang dimiliki siswa tidak bisa diketahui perkembangannya.

4. Mayoritas guru Madrasah Ibtidaiyah belum pernah melakukan peneltian, misalnya PTK (Peneltian Tindakan kelas).Sehingga pembelajaran kurang dinamis dan variatif.

\section{Kesimpulan}

Kompetensi profesional guru Madrasah Ibtidaiyah di Kota Salatiga sudah baik. Kompetensi profesinal yang belum dilaksanakan guru Madrasah Ibtidaiyah di Kota Salatiga yaitu guru mengajar tidak sesuai dengna disiplin ilmu yang dikuasai, penggunaan media pembelajaran berbasis teknologi, dan research and development penelitian yang belum pernah dilakukan.

Beberapa faktor yang mempengaruhi kompetensi profesional guru Madrasah Ibtidaiyah dalam meningkatkan mutu pendidikan Madrasah Ibtidaiyah di Kota Salatiga yang meliputi: motivasi guru, fasilitas kerja, etos kerja guru, supervisi akademik, kondisi sosial ekonomi. Dampak kompetensi profesional guru dalam meningkatkan mutu pendidikan di Madrasah Ibtidaiyah di Kota Salatiga adalah pembelajaran optimal, proses pembelajaran nyaman dan menyenangkan, hasil pembelajaran sesuai dengan 
perkembangan zaman, dan hasil pembelajaran dinamis dan kompetitif.

\section{Daftar Pustaka}

Bogdan dan Biklen. 1982. Qualitative Research For Education: An Introduction To Theory and Methods. Boston: Allyn andBacon.Inc.

Depdiknas. 2001. Manajemen Peningkatan Mutu Berbasis Sekolah. Jakarta.

Ibrahim Bafadal. 2003. Peningkatan Profesional Guru. Jakarta:

Bumi Aksara.

Ma'mur Asmani Jamal. 2009. 7 Kompetensi Guru Menyenangkan dan Profesional. Jakarta: Powerbooks.

Muhaimin \& Abdul Mujib. 1993. Pemikiran Pendidikan Islam : Kajian Filosofis dan Kerangka Dasar Operasionalisasanya. Bandung:Trigenda Karya.

Mulyasa. 2008. Standar Kompetensi dan Sertifikasi Guru. Bandung: Remaja Rosdakarya.

Mujtahid. 2009. Pengembangan Profesi Guru. UIN Malang Press.

Moleong J. Lexy. 2009. Metodologi Penelitian Kualitatif.. Bandung Remaja Rosdakarya.

Miles Huberman. 1992. Analisis Data Kualitatif: Buku Sumber Tentang Metode-Metode Baru, . Terj. Tjejep Rohendi. Jakarta: UI Press

Nazir Moh. 1999. Metode Penelitian. Jakarta: Galia. 
Rahim Husni. 2001. Arah Baru Pendidikan Islam di Indonesia. Jakarta: Logos.

Sarimaya Farida. 2008. Sertifikasi Guru: Apa, Mengapa, dan Bagaimana, Bandung: Yrama Widya.

Suharsimi Arikunto. 2002. Prosedur Penelitian Suatu Pendekatan Praktis. Jakarta: Rineka Cipta.

Sutopo. 1990. Metodologi Penelitian Qualitatif I: Dasar Teoritis dan Karakteristiknya. Surakarta: UNS.

Wijaya Cece dan Tabrani Rusyan.1991. Kompetensi Dasar Guru Dalam Proses Belajar Mengajar. Bandung: Remaja Rosdakarya. 